\title{
TNFSF13B wt Allele
}

National Cancer Institute

\section{Source}

National Cancer Institute. TNFSF13B wt Allele. NCI Thesaurus. Code C94788.

Human TNFSF13B wild-type allele is located within 13q32-q34 and is approximately $56 \mathrm{~kb}$ in length. This allele, which encodes tumor necrosis factor ligand superfamily member 13B protein, plays a role in both the regulation of lymphocyte proliferation and signal transduction. 